peak of combined acidic and neutral amino-acids and the peak given by phenylalanine and tyrosine at about $80 \mathrm{ml}$. In a test of the experimental conditions by analysis carried out on the $50 \mathrm{~cm}$. column, 1 umole of a sample of ASA gave, after standing at $p \mathrm{H} 2$ for $24 \mathrm{hr}$, at $20^{\circ}, 0.04$ umole of ASA, $0.04 \mu$ mole of $B$ and $0.69 \mu \mathrm{mole}$ of $C$. After increasing the time of standing to $48 \mathrm{hr}$. the values were $0.01 \mu$ mole of ASA, $0.04 \mu$ mole of $B$ and $0.71 \mu$ mole of $C$.

Provisionally we are applying a correction factior to compensate for the 75 per cent recovery of ASA as the anhydrides.

In practice, samples of urine and deproteinized plasma are brought to $p \mathrm{H} 2$ by the dropwise addition of $2 \mathrm{~N}$ hydrochloric acid and are allowed to stand at room temperature for $48 \mathrm{hr}$. prior to analysis.

Miles Laboratories Inc. and the Ames Co., Itd., provided a generous grant for the construction of the automatic amino-acid analyser which was built in the Medical Unit by Mr. C. E. Glover and Mr. G. Marshall.

One of us (D. C. C.) is indebted to the Drummond Trust for a senior fellowship.

D. C. Cusworth

R. G. Westall

Medical Unit,

University College Hospital Medical School, University Street, London, W.C.1.

Allan, J. D., Cusworth, D. C., Dent, C. E., and Wilson, V. K., Lancet, i, 182 (1958).

${ }^{2}$ Westall, R. G., Proc. Fourth Intern. Congr. Biochem., Vienna, 168 (1958). ${ }^{3}$ Ratner, S., Petrack, B., and Rochovansky, O., J. Biol. Chem., 204,

+ Westall, R. G., Biochem. J., 77, 135 (1960).

${ }^{5}$ Cusworth, D. C., and Dent, C. E., Biochem. J., 74, 550 (1960).

${ }^{6}$ Moore, S., and Stein, W. H., J. Biol. Chem., 211, 893 (1954).

Spackman, D. H., Stein, W. H., and Moore, S., Anal. Chem., 30 $1100(1958)$.

'Stein, W. H., and Moore, S., J. Biol. Chem., 211, 915 (1954).

\section{Chromatographical Separation of Carbohydrate O-Isopropylidene Derivatives}

DURING investigations on fluorocarbohydrates, it became necessary to examine the purity of small amounts of $O$-isopropylidene derivatives. Hitherto, for such compounds in the carbohydrate series, there has been no reliable chromatographical method of separation from fully protected or nearly related hydroxylated compounds. We have found, however, that separations can be achieved rapidly and easily by reversed-phase, ascending chromatography on cellulose acetate strips $(20 \times 4.5 \mathrm{~cm}$., as used for electrophoresis and obtainable from Oxo, Ltd., Queen Street Place, London, E.C.4).

Strips were washed thoroughly in methanol and dried in air. Compounds $(50-800 \mu \mathrm{gm}$. in ethanol) were applied as spots to the washed strip which were then developed by ascending chromatography with a mixture of methanol and water $(6 / 4 \mathrm{v} / \mathrm{v})$. The separation was achieved in $2 \mathrm{hr}$. at $2-5^{\circ} \mathrm{C}$.

After drying for $20-25 \mathrm{~min}$. in air at room temperature, compounds can be detected in two ways :

(a) Developed chromatograms are immersed in a solution $^{1}$ of 2,4-dinitrophenylhydrazine $(0 \cdot 4$ per cent $\mathrm{w} / \mathrm{v}$ ) in $2 \mathrm{~N}$ hydrochloric acid. Carbonyl, $\mathrm{O}$-isopropylidene and $O$-benzylidene compounds appear as deep yellow zones which are further intensified when the chromatogram is washed briefly in aqueous sodium hydroxide (10 per cent $\mathrm{w} / \mathrm{v})$. (b) Alternatively, the developed chromatograms are floated on the surface of a solution ${ }^{2}$ ( 1 per cent $\mathrm{w} / \mathrm{v}$ ) of potassium permanganate in $1 \mathrm{~N}$ sulphuric acid for $2 \mathrm{~min}$. and immersed for a further minute. The chromatogram is then washed in running water, when the components appear as sharply defined purple-brown spots, which turn brown on standing. This is sensitive to about $150 \mu \mathrm{gm}$. of such compounds as $1,2: 5,6$-di- $O$-isopropylidene-D-glucose.

\begin{tabular}{|c|c|c|}
\hline Substance ${ }^{\text {Table } 1}$ & $R_{F}$ & $\begin{array}{l}\text { No. of } \\
\text { free hydroxyl } \\
\text { groups }\end{array}$ \\
\hline $1,2: 4,5$-di- $O$-isopropylidene-3-mesyl-D-fructose & $0 \cdot 15$ & 0 \\
\hline $1,2-0$-benzylideneglycerol & $0 \cdot 23$ & 1 \\
\hline Methyl 0 -isopropylidene-DL-glycerate & 0.28 & a \\
\hline 1,2:3,4-di-O-isopropylidene-6-tosyl-D-galactose & $0 \cdot 32$ & 0 \\
\hline Methyl $2,3-O$-isopropylidene- $\alpha \beta$-D-ribofuranoside & $0 \cdot 48$ & 1 \\
\hline $1,2: 5,6$-di- $O$-isopropylidene-D-glucose & 0.52 & 1 \\
\hline $1,2: 3,4$-di- $O$-isopropylidene-D-galactose & $0 \cdot 55$ & 1 \\
\hline $1,2-O$-isopropylideneglycerol & $0 \cdot 65$ & 1 \\
\hline Methyl DL-glycerate & $0 \cdot 66$ & 2 \\
\hline$( \pm)$-butan-1;3-diol & $0 \cdot 73$ & 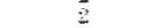 \\
\hline 2-O-isopropylidene-D-glucofuranose & 0.80 & 3 \\
\hline $3,4,6$-tetra-O-methyl-D-glucose & 0.90 & 1 \\
\hline Methyl $2,3,6$-tri- $O$-methyl- $\alpha \beta$-D-glucoside & 0.98 & 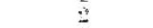 \\
\hline 3-O-methyl-D-glucose & 0.98 & 4 \\
\hline
\end{tabular}

As seen from the list of $R_{F}$ values in Table 1 , the method in general can be used to distinguish fully protected sugars from those with one or more free hydroxyl groups. In general, unsubstituted sugars move at the solvent front.

\section{J. E. G. BARNETT P. W. KENT}

Department of Biochemistry, University of Oxford.

${ }^{3}$ Bland, D. E., Nature, 164, 1093 (1949).

${ }^{2}$ Procházka, Ž., Chem. List, 44, 43 (1950); Chem. Abs., 45, 5561。 (1951).

\section{Isolation of Histones(?) from Staphylococcus aureus}

ANy theories that try to give an explanation of the function of histones have had in the past to take account of the reported absence of histones from bacteria $^{1,2}$. If histones are solely concerned with cell differentiation or 'gene suppression' in multicellular organisms, then one might expect them to be absent from bacteria and protozoa ${ }^{3,4}$. But if, on the other hand, they have an even more fundamental function, related to the function of deoxyribonucleic acid (DNA) in all cells, then they should also be present in unicellular organisms.

In the present investigation an attempt was made to extract basic proteins from bacteria, following a modification of the procedure routinely used in our laboratory for the isolation of histones from cell nuclei ${ }^{5}$.

The bacteria, Staphylococcus aureus, were washed with 4 per cent acetic acid, and then defatted and dried by washing several times with ethanol and then with ether. This procedure denatures many of the non-basic proteins, rendering them insoluble on extraction with acid. The acid-soluble proteins were extracted by grinding the dried bacteria with glass powder in the presence of $0 \cdot 1 \mathrm{~N}$ sulphuric acid, and then centrifuging. Large amounts of non-protein material extracted were removed by dialysis against $0 \cdot 1 N$ sulphuric acid, and the proteins were precipitated from the dialysed extract by the addition of seven volumes of ethanol, and dried with ethanol followed by ether.

Some of the extracted material was subjected to starch-gel electrophoresis in the presence of $4 M$ urea 